\title{
Burseramyia braziliensis, a new species of gall midge (Diptera, Cecidomyiidae, Asphondyliini) associated with Swartzia langsdorffii Raddi (Fabaceae)
}

\author{
Valéria Cid Maia ${ }^{1,2,4}$ \& Karina Figueiredo Fonseca ${ }^{1,3}$ \\ ${ }^{1}$ Departamento de Entomologia, Museu Nacional, \\ Quinta da Boa Vista, São Cristóvão, CEP 20940-040, Rio de Janeiro, RJ, Brazil \\ ${ }^{2}$ Bolsista de produtividade do $\mathrm{CNP} q$ \\ ${ }^{3}$ Bolsista PIBIC/CNPq/UFRJ \\ ${ }^{4}$ Corresponding author: Valéria Cid Maia, e-mail: maiavcid@acd.ufrj.br
}

MAIA, V.C. \& FONSECA, K.F. Burseramyia braziliensis, a new species of gall midge (Diptera, Cecidomyiidae, Asphondyliini) associated with Swartzia langsdorffii Raddi (Fabaceae). Biota Neotrop. 11(4): http://www. biotaneotropica.org.br/v11n4/en/abstract?article+bn00611042011.

Abstract: Burseramyia braziliensis Maia \& Fonseca, a new species of Cecidomyiidae (Diptera) that induces leaf galls on Swartzia langsdorffi Raddi (Fabaceae) is described and illustrated (larva, pupa, male and female) based on material from restinga areas of Bertioga, São Paulo, Brazil. Until now, Burseramyia was known from one galling species, Burseramyia burserae Möhn, 1960, restricted to El Salvador. The genus is easily recognizable by the shape of the gonostylus (equally subdivided into toothed and setose portions). The new species differs from the previously described species mainly in the number and shape of terminal papillae (larva), shape of hypropoct (male) and method of pupation.

Keywords: diversity, gall, neotropical, restinga, taxonomy.

MAIA, V.C. \& FONSECA, K.F. Burseramyia braziliensis, uma nova espécie de cecidomiídeo (Diptera, Cecidomyiidae, Asphondyliini) associada a Swartzia langsdorffii Raddi (Fabaceae). Biota Neotrop. 11(4): http://www.biotaneotropica.org.br/v11n4/pt/abstract?article+bn00611042011.

Resumo: Burseramyia braziliensis Maia \& Fonseca, uma nova espécie de Cecidomyiidae (Diptera) que induz galhas foliares em Swartzia langsdorffi Raddi (Fabaceae) é descrita e ilustrada (larva, pupa, macho e fêmea) com base em material de áreas de restinga de Bertioga, São Paulo, Brasil. Até o momento, Burseramyia era conhecida de uma única espécie galhadora, Burseramyia burserae Möhn, 1960, restrita a El Salvador. O gênero é facilmente reconhecido pela forma do gonóstilo (igualmente dividido em uma porção denteada e em outra com cerdas). A nova espécie difere da previamente descrita principalmente no número e forma das papilas terminais (larva), forma do hipoprocto (macho) e método de pupar.

Palavras-chave: diversidade, galha, neotropical, restinga, taxonomia. 


\section{Introduction}

Swartzia Schreb is a large genus of Fabaceae with 127 species restricted to Central and South America, 114 of them occurring in Brazil (Mansano 1997). Three kinds of galls, all induced by Cecidomyiidae, are known from this genus. Two were described by Rübsaamen (1908) from the Amazon, Brazil: one of those is a complex bifid leaf gall on Swartzia stipulifera Harms., the other a simple concave spot gall on Swartzia sp. The gall inducers were not described and the galls have never been recorded again. The third cecidomyiid gall was described by Maia et al. (2008) from São Paulo, Brazil, on Swartzia langsdorffii Raddi, being formed by the coalescence of two sides of a leaf. The cecidomyiid responsible for that gall is herein described.

The new species is placed here in the genus Burseramyia Möhn, 1960 (Cecidomyiidi: Asphondyliini: Schizomyiina) to which it readily keys in Gagné (1994). Burseramyia is otherwise known from one species, B. burserae Möhn, 1960, that is responsible for a flower gall on Bursera simaruba (L.) Rose (Burseraceae) in El Salvador. The two species of Burseramyia are generally similar in the male and female terminalia, mostly differing in larval characters. The pupa of B. burserae is unknown. Burseramyia is characterized by four-segmented palpi, the gonostylus subdivided into toothed and setose portions, a narrow, pointed aedeagus, and a hard, pigmented, elongate ovipositor devoid of setae.

\section{Materials and Methods}

Galled leaves of Swartzia langsdorffii were collected in Bertioga (46 $08^{\circ}$ ' 19" W and 23 51' 16" S), São Paulo, Brazil from April, 2004 to March, 2005 and taken to the laboratory where some samples were dissected to observe the internal chamber and to obtain larvae. Other samples were kept in plastic pots layered at the bottom with damp cotton and covered by a fine screen to obtain adults and pupal exuviae. All specimens were first preserved in $70 \%$ ethanol and then mounted on slides following the methodology of Gagné (1994). All specimens are deposited in the Museu Nacional, Rio de Janeiro.

\section{Results}

Burseramyia braziliensis Maia \& Fonseca, new species (Figures 1-16)

Adult-Head (Figure 1): eye facets circular, all closely approximated. Antenna with obconic scape and globose pedicel; male flagellomeres with short necks, those of female without, with proportions of flagellomeres 8-12 as shown in Figures 2 and 3; circumfila sinuous in both sexes (Figures 4 and 5). Flagellomeres 1 and 2 connate. The $12^{\text {th }}$ female flagellomere ovoid. Frons with 1922 setae. Labrum triangular with three pairs of ventral setae. Labella hemispherical with lateral and mesal setae. Palpus with four setose segments, the first globose, the second one ovoid and the others cylindrical.

Thorax. Wing (Figure 6): length from arculus to apex: 2.26$2.55 \mathrm{~mm}$ in male $(\mathrm{n}=3)$ and $2.02-2.65 \mathrm{~mm}$ in female $(\mathrm{n}=6)$. Anepimeron with 45-47 setae in male and 37-58 setae in female. Other pleura bare. Tarsal claws similar on both sexes, curved beyond midlength, simple and similar on all legs; pulvilli absent and empodium not reaching bend in claws (Figure 7).

Abdomen. Male (Figure 8): tergites 1-7 oblong with single complete row of caudal setae, few lateral setae, and the rest of the body with scattered scales. Tergite 8 with two basal trichoid sensilla (setae and scales absent). Sternites 1-7 with a complete row of caudal setae, some lateral and mesal setae and two basal trichoid sensilla. Sternite 8 oblong with scattered setae and two trichoid sensilla.

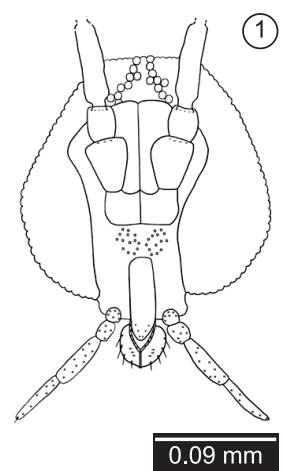

(5)

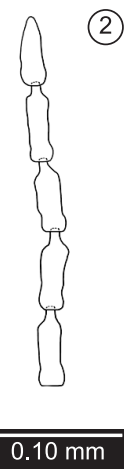

$0.10 \mathrm{~mm}$

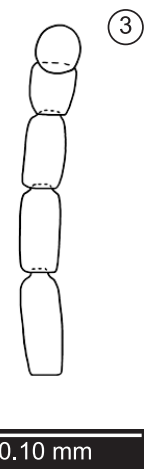

(7)

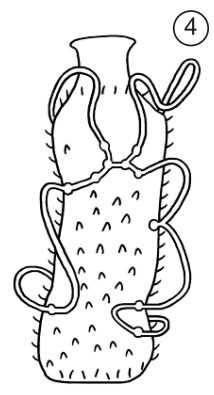

$\overline{0.04 \mathrm{~mm}}$
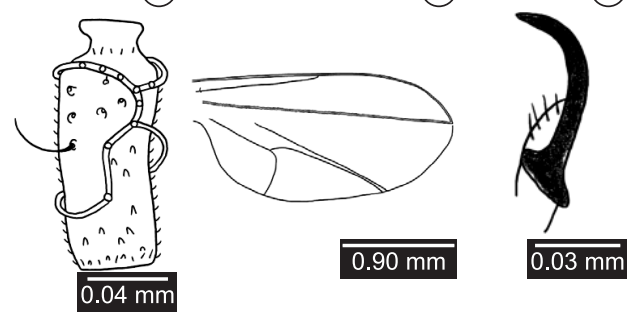

(8)

Figures 1-8. Burseramyia brasiliensis sp.n. Adult: 1: female, head, frontal view; $2: 8^{\text {th }}-12^{\text {th }}$ male flagellomeres; $3: 8^{\text {th }}-12^{\text {th }}$ female flagellomeres; $4: 3^{\text {rd }}$ male flagellomere; $5: 3^{\text {rd }}$ female flagellomere; 6 : male wing; $7:$ male foreleg, tarsal claw and empodium; $8: 5^{\text {th }}-8^{\text {th }}$ male abdominal segments, lateral view. Scale bars in $\mathrm{mm}$.

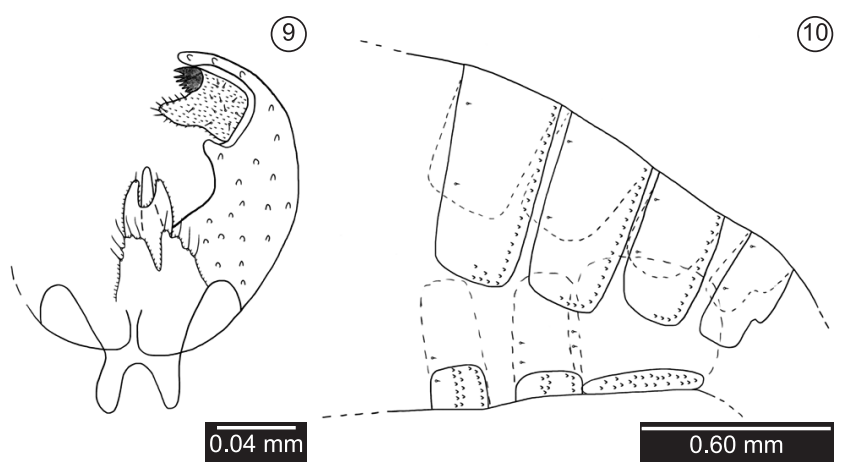

Figures 9-10. Burseramyia brasiliensis sp.n. Adult: 9: male terminalia, dorsal view; 10: $5^{\text {th }}-8^{\text {th }}$ female abdominal segments, lateral view.

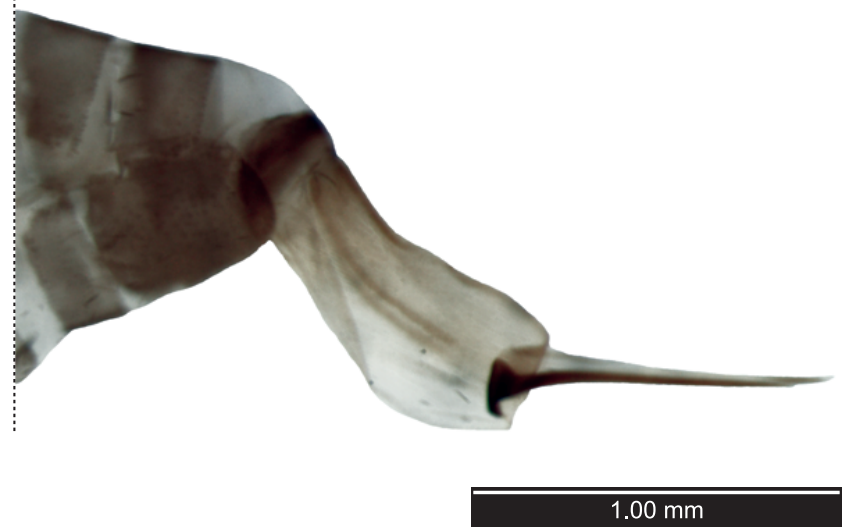

Figure 11. Burseramyia brasiliensis sp.n., ovipositor, lateral view. 
(12)

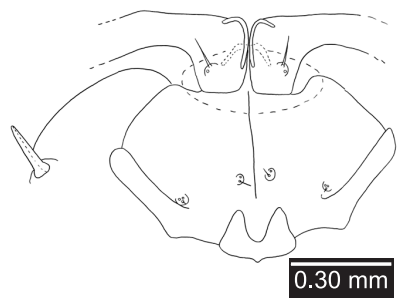

(14)

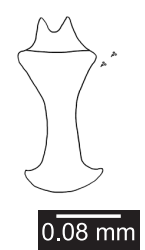

(13)

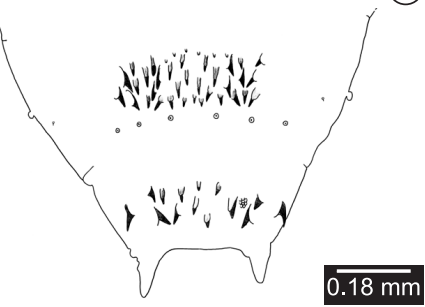

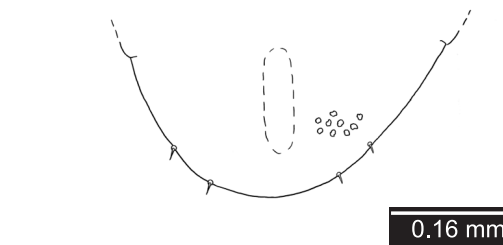

Figures 12-15. Burseramyia brasiliensis sp.n., immature stages. 12: pupal head, frontal view; 13: pupal $8^{\text {th }}$ and $9^{\text {th }}$ abdominal segments, dorsal view;14: larval spatula and lateral papillae, ventral view; 15: larval terminal segment, dorsal view.

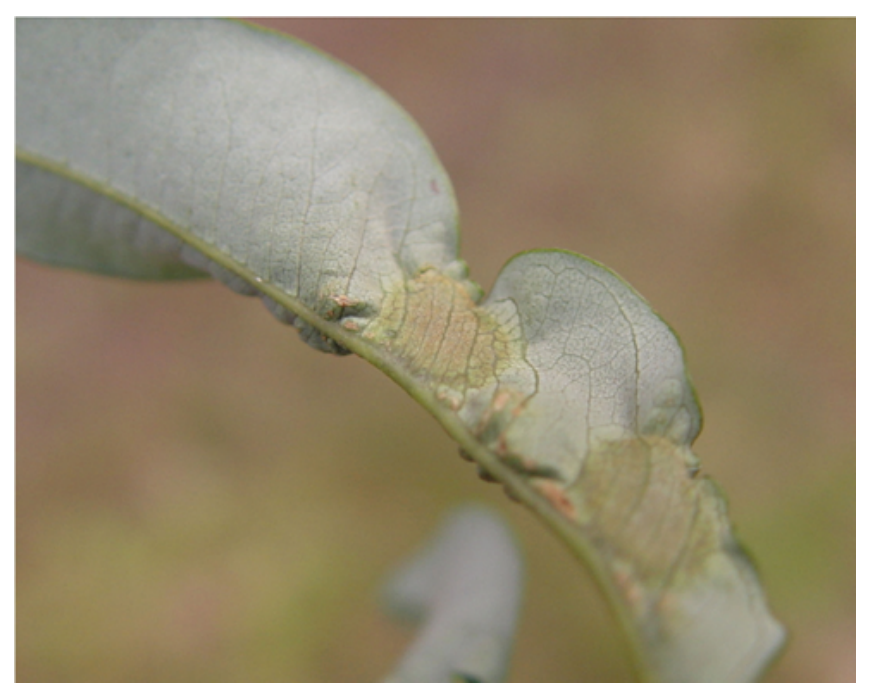

Figure 16. Gall of Burseramyia brasiliensis sp.n. on Swartzia langsdorfii (Fabaceae).

Male terminalia (Figure 9): gonocoxites slender and setose; gonostylus reniform, setose, and setulose. Cercus triangular, separated almost to base and setose. Hypoproct bilobed, setulose and with a pair of apical setae. Aedeagus slim and longer than hypoproct. Parameres absent. Female abdomen (Figure 10): tergites 1-7 as in male; tergite 8 sclerotized with only two basal trichoid sensilla. Sternites 1-7 as in male. Ovipositor (Figure 11): strongly protrusible and striate; rigid portion 1.58 times as long as sternite 7 .
Pupa-Brownish: Length 3.25-4.59 mm ( $\mathrm{n}=5)$. Head (Figure 12): antenna bases do not form horns; cephalic setae 0.062-0.082 mm long $(n=7)$; two pairs of lower facial papillae (one pair setose, the other asetose); three pairs of lateral facial papillae: one pair setose, the others without setae; upper facial margin thickened laterally. No frontal spines. Thorax: prothoracic spiracle setiform, elongate; 0.10-0.15 mm long $(\mathrm{n}=7$ ) (Figure 12). Abdomen: segments 2-9 with transverse rows of dorsal spines (Figure 13). Terminal segment (Figure 13) with two lateral, apical lobes in both sexes.

Larva-Body elongate and cylindrical. Length: $3.00-5.22 \mathrm{~mm}$ $(n=22)$. Spatula with two teeth. Two sets of three lateral papillae on each side of spatula (two of them with setae) (Figure 14). Convex terminal segment with two setose pairs of terminal papillae (Figure 15).

Gall-Circular leaf gall, yellowish, glabrous, 4-5 mm diameter $(n=2)$, one-chambered, causing leaf coalescence (Figure 16). The gall is not abundant and has a very restricted distribution, being found in a single locality (Fazenda Pinto) in Bertioga.

Material examined-Holotype male, Brazil, São Paulo: Bertioga, 27.IV.2005, V. Maia col., MNRJ. Paratypes, same data-1 male, 2 females and 5 pupal exuviae; same locality and collector-1 larva, 24.VI.2004; 1 larva, 23.IX.2004; 8 larvae and 1 pupal exuvium, 16.XI.2004; 1 pupa, 30.III.2005.

Etymology-The specific name refers to the country where the new species was found.

Comments-Although the newly described species is placed in Burseramyia because of similarities in the male and female genitalia, there are some definite differences between the two, chiefly in the setation of the terminal setae of the larvae. B. burserae has four pairs of papillae, one of them large-corniform, the other three with setae barely evident, while the new species has only two pairs of papillae, each with visible setae. Furthermore, the hypoproct of $B$. braziliensis is more deeply incised than that of $B$. burserae. Another difference between the two species is that $B$. braziliensis pupates inside the gall, whereas $B$. burserae pupates in the soil.

\section{Acknowledgements}

We thank CNPq for financial support (301197/2007-5) and Dr. Raymond J. Gagné (U.S. National Museum) for critical review.

\section{References}

GAGNÉ, R.J. 1994. The gall midges of the Neotropical region. Ithaca, Cornell University Press, $352 \mathrm{p}$.

MAIA, V.C., MAGENTA, M.A.G. \& MARTINS, S. E. 2008. Ocorrência e caracterização de galhas de insetos em áreas de restinga de Bertioga (São Paulo, Brasil). Biota Neotrop. 8(1):167-197. http://dx.doi.org/10.1590/ S1676-06032008000100020

MANSANO, V.F. 1997. Estudos taxonômicos da tribo Swartzieae (DC.) Benth. (Leguminosae - Papilionoideae) no Sudeste do Brasil. Dissertação de Mestrado, Universidade Estadual de Campinas, Campinas, 140p.

RÜBSAAMEN, E.H. 1908. Beiträge zur Kenntnis aussereuropäischer Zoocecidien. III. Beitrag: Gallen aus Brasilien und Peru. Marcellia 7:15-79. 
